\title{
The distributional patterns of surface-dwelling insects in a Tenerife stream (Canary Islands)
}

\author{
B. Malmqvist ${ }^{1}$ \\ A.N. Nilsson 1 \\ M. Baez ${ }^{2}$
}

Keywords : Heteroptera, Gyrinidae, stream pools, predators, Canary Islands.

Eight surface-living insect species, two gyrinid beetles and six heteropteran bugs, were studied in 27 pools in a Tenerife stream. Gyrinus urinator was on average the most abundant species whereas Velia lindbergi was the most widely distributed one. Gyrinid abundance (numbers per pool), but not density (numbers per square metre), was positively associated with pool size and depth. In contrast, the densities of the bugs Velia lindbergi and Hydrometra stagnorum decreased with pool size. Both the number of species and individuals increased with pool area. Widely distributed species were represented with higher average densities than species with a more restricted distribution. Contrary to theory, there was a positive relationship between mean adult body size and density within the guild.

Types de répartitions d’insectes vivant à la surface dans une rivière de Ténérife (Iles Canaries)

Mots clés : Heteroptera, Gyrinidae, mouilles, prédateurs, lles Canaries.

8 espèces d'insectes vivant à la surface, 2 coléoptères Gyrinidés et 6 hétéroptères, ont été étudiées dans 27 stations lentiques (mouilles) d'une rivière de Ténérife. Gyrinus urinator est l'espèce la plus abondante et Velia lindbergi l'espèce la plus largement répandue.

Il existe une corrélation positive entre l'abondance des Gyrinidés (nombre par station) mais non leur densité (nombre par $\mathrm{m}^{2}$ ) et la taille et la profondeur des stations.

Par contre, les densité de Velia lindbergi et Hydrometra stagnorum diminuent avec la taille des stations.

Le nombre d'espèces et celui des individus croissent avec la superficie de la station.

Les espèces à large répartition sont présentes avec des densités plus élevées que les espéces moins largement distribuées.

Contrairement à la théorie, il apparaît une corrélation positive entre la densité et la taille moyenne du corps des adultes de ce peuplement.

\section{Introduction}

Typically, stream reaches are composed of sequences of channel units each of which has unique hydraulic and geomorphic features. Such distinct channel units are major determinants of the habitats of aquatic organisms (Sedell et al. 1990). Leopold et al. (1964) recognized two such units, riffles and pools. While the water surface of riffles usually lacks animals, that of pools may host a

1. Department of Animal Ecology, University of Umea, Sweden.

2. Department of Zoology, University of La Laguna, 38206 La Laguna, Tenerife, Canary Islands, Spain. variety of species. One explanation for this is undoubtedly related to the relatively weak current velocity which allows exploitation of the pool habitat.

Larval and adult heteropteran water bugs (Gerromorpha) and adult whirligig beetles (Gyrinidae) are some of the most predominant members of the community of surface-dwelling species, which is sometimes referred to as the neustonic community (Anderson \& Wallace 1984), being predators or scavengers on animals trapped on the surface film (Ekblom 1926, Usinger 1956). Although there is some information on habitat partitioning among species of gyrinids (Brinck 1955, Leech \& Chandler 
1956, Istock 1966, Kolmes 1984) and water bugs (Vepsäläinen 1973, Spence 1981, Spence 1983), we are not aware of any previous study that, in a reach of a river system, has included distributional patterns of the entire guild of surface-living insects and their potential interactions.

Insects on the water surface, easily observed and collected, provide an almost ideal system for studying various ecological processes, including predation, competition and relationships with abiotic environment. Here, we present analyses of the species structure in 27 pools and its relationships with pool area and other environmental factors in a Tenerife stream.

\section{Materials and methods}

We define the surface-living guild as species which dwell on the water surface, where they also mainly take their prey and which rarely enter the water column. Therefore, Notonecta canariensis Kirkaldy and $A$ nisops sp., although temporarily at the water surface, and observed in several of the studied pools, were not included in the analyses. Pisaurid spiders, suggested by Spence (1983) to influence gerrid distributions, were not observed.

Abundance is defined as the number of ind/pool, density the numbers per square metre, and frequency represents the proportion of all pools in which a species is found.

Field sampling was carried out on 18 and 19 April 1991 using hand-nets. Initially, in each pool, our efforts were directed at catching all gyrinids. Then all observed heteropteran specimens on the water surface were collected. Finally, sampling was performed in all stands of vegetation and under stones turned over around the pools. Surface area was estimated by approximating the pools to either ellipses, squares or rectangles. Maximum depth, vegetation cover (in square metres), distance to the next upstream pool, and the position of each pool were also included in the analysis. The latter variable could also be considered as a relative measure of altitude. Finally, the presence of cover, defined as rocks with crevices and aggregates of stones with interstices, was rated as either unavailable, or of low or high availability.

Gyrinids were identified directly in the field ( $G$. urinator is reddish and $G$. dejeani black beneath) and released thereafter. Heteropteran bugs were preserved in $70 \%$ alcohol and identified in the laboratory, where also the different larval instars were separated. Larval instars were recognized by measuring head width, total body length and width, and the length of the mesotibia at 12 times magnification.

Gyrinids are engulfers, whereas hemipterans pierce their victims and suck out the body fluids. Therefore, mouthpart morphology (or head width) does not effectively reflect niche measures. As a comparable measure for different taxa we used instead dry mass. This was measured to the nearest $0.1 \mathrm{mg}$ using a Mettler AE 50, except for the three smallest hemipteran species for which a Cahn electrobalance (precision $0.001 \mathrm{mg}$ ) was used.

Statistical methods included linear regression, bivariate Pearson correlation, and Student's t-test (two-tailed). A significance level of $5 \%$ was used except in cases with multiple correlations, where pvalues were Bonferroni adjusted (Holm 1979).

\section{Habitat description}

The studied stream system, Barranco de Afur, is situated on the northern part of the Anaga peninsula $\left(28^{\circ} 33^{\prime} \mathrm{N}, 16^{\circ} 15^{\prime} \mathrm{W}\right)$, Tenerife, Canary Islands. The geology here is characterized by miocene basalts. Our study was carried out at an altitude bet ween about 180 and $280 \mathrm{~m}$ a s 1 . The stream valley is cultivated, except in steeper parts, where introduced plants such as prickly pear (Opuntia sp.) are common. The stream is one of the few permanent streams of the island. European eel, Anguilla anguilla (Linnaeus), is present in pools up to about $200 \mathrm{~m}$ a s 1 . Further information about the aquatic animals of this stream, and others in Tenerife, is provided by Malmqvist et al. (in press).

The stream is open to direct sunlight due to a lack of riparian trees, except for occasional specimens of Salix canariensis Link, and, in some sections (though not in sampled reaches), by stands of Arundo donax Linnaeus. Several plant species were found in and at the margins of the pools, including Apium? nodiflorum (Linnaeus) Lagasca y Segura, Callitriche sp., Equisetum sp., Fumaria sp., Juncus sp., Mentha ? longifolia Linnaeus, Nasturtium officinale Robert Brown, Polygonum salicifolium Willdenow, Rubus sp., and grasses. In April, the aquatic and streamside vegetation is far from fully developed. 
Twenty-seven pools (surface area : $0.2-17.9 \mathrm{~m}^{2}$; $\overrightarrow{\mathbf{x}}=4.7 \mathrm{~m}^{2}$, maximum depth $: 0.08-1.1 \mathrm{~m} ; \overrightarrow{\mathrm{x}}=$ $0.37 \mathrm{~m}$ ) were sampled. These were situated along an approximately $2 \mathrm{~km}$ section of the stream spanning some $100 \mathrm{~m}$ vertically. Two of the pools were in a small tributary entering the main channel about midway along the investigated section. Discharge ranged from $0.2 \mathrm{~L} \mathrm{~s}^{-1}$ in the tributaries to $13 \mathrm{~L} \mathrm{~s}^{-1}$ in the lower part of the main channel.

In Tenerife, there are nine species of surface-living predators/scavengers in Gyrinidae and Gerromorpha (Balke et al. 1990, Heiss \& Baez 1990). There are two gyrinids, Gyrinus urinator Illiger and $G$. dejeani Brullé, and seven water bugs, Velia lindbergi Tamanini, Hydrometra stagnorum (Linnaeus), Gerris thoracicus Schummel, Merragata hebroides Buchanan-White, Hebrus pusillus (Fallén), Microvelia gracillima Reuter and Mesovelia vittigera Horvath. Information on habitats and food of these species is scanty, except for the widespread Hydrometra stagnorum and Gerris thoracicus. Extrapolating from studies on congeneric species, the ones in Tenerife all seem to fall broadly within the common guild of predatory/scavenging, surface-living insects which inhabit stream pools and other lentic waters (Ekblom 1926, Usinger 1956, Istock 1966, Vepsäläinen 1973, Spence 1981).

\section{Results}

\subsection{General observations}

In total, 833 individuals of eight semiaquatic species, two gyrinids and six heteropterans, were captured (Table 1). Velia lindbergi was the most frequent species occurring in 23 out of 27 pools, whereas Merragata hebroides and Microvelia gracillima were each found in only a single pool. The most abundant species was Gyrimus urinator which, on average, was represented by 23.5 individuals in the pools in which it occurred. The highest observed numbers in a single pool of the two most abundant species, Velia lindbergi and Gyrinus urinator, were 71 and 50 individuals, respectively.

Log average abundance increased significantly with the number of pools in which the species were found (Fig. 1). Species distributions showed a slightly bimodal pattern.

Small species were rare while larger species were present in relatively high densities (Fig. 2). A linear regression analysis indicated that the increase in density with adult size was significant $\left(R^{2}=0.76, p<\right.$ $0.01)$. The validity of the relationship was independent of whether all individuals were included or only adults.

\subsection{The species}

The two gyrinid beetles often occurred together, often in mixed aggregations, and their abundances were significantly correlated $(\mathrm{r}=0.79)$. G. urinator was almost ten times more abundant than $G$. dejeani (Table 1). Both species showed increasing abundances with increasing pool area and maximum water depth (Table 2).

Larvae of $\boldsymbol{V}$. lindbergi were assigned to five different instars which could be separated by head width.

Table 1. Data on the proportion of all pools with the species (frequency), mean pool abundances (in those with the species) and maximum abundance. Data for gyrinids refer to adults only, others to larvae and adults.

Tableau 1. Abondance relative (fréquence) des especes dans toutes les stations, abondance moyenne par station et abondance maximum. Les données sur les Gyrinidés ne concernent que les adultes, les autres concernent larves et adultes.

\begin{tabular}{lcccc}
\hline \multicolumn{1}{c}{ Species } & Frequency & Mean pool & \multicolumn{1}{c}{ SD } & Max pool $^{-1}$ \\
\hline Gyrinus urinator & 0.59 & 23.5 & 14.5 & 50 \\
G. dejeani & 0.59 & 2.9 & 2.4 & 9 \\
Velia lindbergi & 0.85 & 11.5 & 17.3 & 71 \\
Hydrometra stagnorum & 0.81 & 4.0 & 3.7 & 14 \\
Gerris thoracicus & 0.26 & 8.1 & 7.2 & 18 \\
Merragata hebroides & 0.04 & 1.0 & - & 1 \\
Hebrus pusillus & 0.11 & 1.0 & - & 1 \\
Microvelia gracillima & 0.04 & 1.0 & - & 1 \\
\hline
\end{tabular}




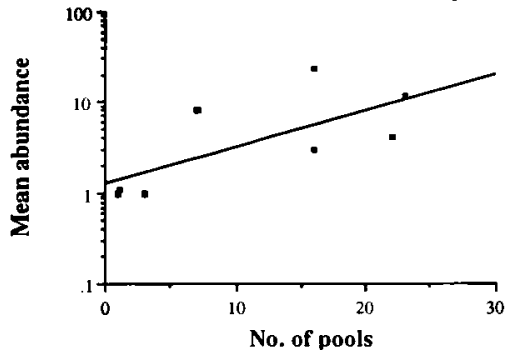

Fig. 1. Plot of the dependence of average abundance on the number of pools in which the species were found.

$y=1.28,10^{0.40 x}, R^{2}=0.50, p=0.049$. The two species in the far left part of the graph are separated only for clarity.

Fig. 1. Relation entre l'abondance moyenne et le nombre de stations où les espèces ont été récoltées. $\mathrm{y}=1.2810^{\circ} .040 \mathrm{x}$, $\mathbf{R}^{2}=0.50, p<0.05$. Les deux espèces le plus à gauche du diagramme ont été séparées pour plus de clarté.

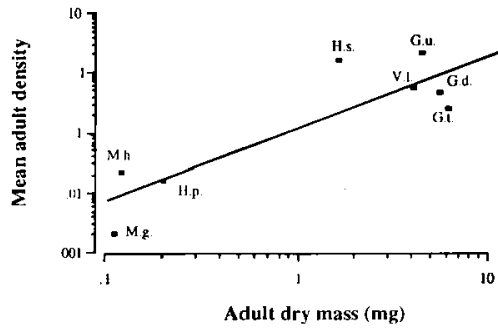

Fig. 2. The relationship between body size (mg dry weight) and mean density (No. $\mathrm{m}^{-2}$ ) of adult insects on the water surface of stream pools in Barranco de Afur, $y=-0.925+1.202 x$, $\mathrm{p}<0.01$. G.d. = Gyrinus dejeani, G.u. = G. urinator, G.t. = Gerris thoracicus, V.1. = Velia lindbergi, H.p. = Hebrus pusillus, H.s. = Hydrometra stagnorum, M.h. = Merragata hebroides and M.g. = Microvelia gracillima. The values for $M$. hebroides and $M$. gracillima are not means since they relate to single values.

Fig. 2. Relation entre le poids (mg/poids sec) et la densité moyenne (No. $\mathrm{m}^{-2}$ ) des insectes adultes en surface des stations de Barranco de Afur. $y=-0.925+1.202 x, p<0.01$. Les valeurs pour $M$. hebroides et $M$. gracillima ne concernent pas des moyennes mais les données brutes.

Table 2. Bivariate Pearson correlation coefficients (Bonferroni probabilities) of the associations between the abundance of semiaquatic species and environmental variables : position (increasing upstream), pool area, maxjmum depth, vegetation (area), cover category (1-3,3 highest) and distance to next upstream pool (m). Area, depth and distance values are (log +1$)$ transformed.

Tableau 2. Coefficients de corrélation de Pearson (Probabilités de Bonferroni) entre l'abondance des espèces semi-aquatiques et les variables dépendantes du milieu (localisation de l'aval vers l'amont) surface de la station, profondeur maximum, surface de la végétation, type de protection (1-3, 3 maximum) et distance (m) à la station amont. Les valeurs de surface, de profondeur et de distances sont transformées, $\log (x+1)$.

\begin{tabular}{lcccccc}
\hline Species & Position & Area & Depth & Vegetation & Cover & Distance \\
\hline Gyrinus urinator & -0.541 & $0.906^{* * *}$ & $0.722^{* * *}$ & 0.332 & 0.229 & 0.140 \\
G. dejeani & -0.261 & $0.678^{* *}$ & $0.578^{*}$ & 0.340 & 0.247 & 0.179 \\
Velia lindbergi & -0.300 & 0.280 & 0.200 & 0.074 & 0.088 & 0.015 \\
Hydrometra stagnorum & -0.351 & 0.011 & -0.196 & 0.069 & 0.069 & 0.169 \\
Gerris thoracicus & -0.129 & 0.296 & 0.110 & 0.462 & 0.419 & 0.011 \\
\hline
\end{tabular}

The population structure suggested one cohort of adults and last instar larvae followed by a second one with a peak in the second instar.

The sex ratio (male : female) of 48 adult $V$. lindbergi was $21: 27=0.78$. In the nearby Barranco de las Canteras taken on 9 April and 31 October 1991, sex ratios were even more skewed towards female dominance, $2: 17,(=0.12)$ and $3: 14(=0.21)$, respectively. In another sample from the nearby island, La Gomera (pond, Las Rosas, 31 Dec 1981), five maies in a sample of 21 adults $(=0.31)$ is further evidence of departure from equal sex ratio in $V$. lindbergi. 
Five adults ( 3 females and 2 males) out of 48 $V$. lindbergi were macropterous and six last instar larvae out of 38 had wingbuds. Combining these data suggests $>12 \%$ wingedness of the population. In Barranco de las Canteras on 9 April 1991, one female in a sample of 19 adults was macropterous $(5.2 \%)$. The stream here dried out later in the season and only small desiccating pools remained by the end of October. Out of seventeen adults no one had wings on this occasion. None in the above mentioned sample from $\mathrm{La}$ Gomera was winged.

Five larval instars of $H$. stagnorum were identified with about equal representation. In contrast to $V$. lindbergi, instars of Hydrometra larvae were not as well separated using head widths.

G. thoracicus occurred in $26 \%$ of the studied pools, in which it was comparatively numerous. Pools where Gerris were present had significantly more vegetation (two-tailed t-test ; $t=3.06, p<$ 0.01 ) and cover (two-tailed $t$-test ; $t=2.57, p<$ 0.05 ) than pools lacking this species. Bivariate correlation between abundance and extension of vegetation was however not statistically significant (Table 2). Adults and larvae were approximately equally abundant. Among the larvae, younger instars prevailed ( $88 \%$ in instars I and II).

Microvelia gracillima was only found in one large pool $\left(17.9 \mathrm{~m}^{2}\right)$ situated in the lower part of the investigated section. This pool had rather extensive vegetation of Apium sp. and was surrounded by blocks ans shallow margins.

Merragata hebroides also occurred in a single pool. This was situated somewhat upstream the middle part of the studied section, and was quite small $\left(1.5 \mathrm{~m}^{2}\right)$ and shallow $(0.1 \mathrm{~m})$ with much grass hanging down into the water and some Polygonum growing in the water. The margin was made up of stones and sand.

Hebrus pusillus was found in three fairly large pools (range $4.6-15.2 \mathrm{~m}^{2}$ ) with a maximum depth of $0.26-0.80 \mathrm{~m}$ situated in the lower and middle sections of the study reach. No consistent vegetation characteristics could be detected (two pools lacking vegetation, the third with abundant grass hanging into the water and some twigs), though boulders were always present at the stream margin, possibly providing cover.
Mesovelia vittigera was not present in the samples, a fact which is related to its phenology. The species seems to be lacking throughout Tenerife in April. However, the species is present in the study stream in other seasons (Malmqvist, Nilsson \& Baez unpubl.).

\subsection{Distribution in relation to environment}

The abundances (numbers per pool) of different species generally showed weak correlations with environmental variables.

The densities (numbers per square metre) of G. urinator, increased significantly with pool area $\left(\mathrm{R}^{2}=0.52, \mathrm{p}<0.001\right)$, whereas those of $V$. lind bergi and $H$. stagnorum decreased $\left(\mathrm{R}^{1} \mathrm{~V} \mid=0.21\right.$, $\left.\mathrm{p}<0.05, \mathrm{R}^{2} \mathrm{Hs}=0.41, \mathrm{p}<0.001\right)$. G. dejeani and $G$. thoracicus densities did not show any response to pool size $\left(R^{2}{ }_{G d}=0.00, R_{G t}^{2}=0.04, p>0.05\right.$ ).

There was a significant increase in the number of species with pool area, although sometimes even small pools were inhabited by up to five species (Fig. $3)$. The z-value for the species-area relationship was $0.26(\mathrm{C}=0.36, r=0.69)$. Also the number of individuals, irrespective of species, was generally increasing with pool size ( $r=0.73$ : Fig. 4).

Bivariate correlations between abundances of species yielded a significant, positive relationship only between the two gyrinid species. However, analyses of the densities of species pairs indicated a strong negative association between $G$. urinator and

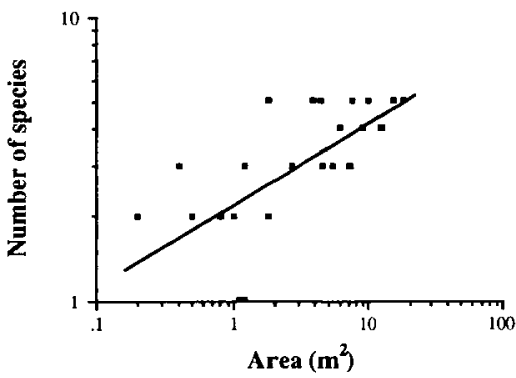

Fig. 3. The relationship between the number of species and pool area $\left(\mathrm{m}^{2}\right)$.

Fig. 3. Relations entre le nombre d'espèces et la surface des stations $\left(\mathbf{m}^{2}\right)$. 


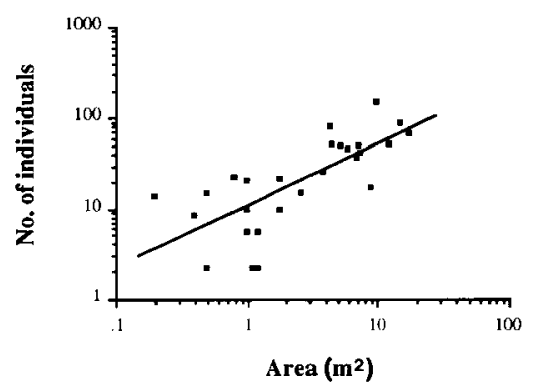

Fig. 4. The relationship between total abundances (species combined) and pool area $\left(\mathrm{m}^{2}\right)$.

Fig. 4. Relations entre les abondances totales (ensemble des espèces) et la surface des stations $\left(\mathbf{m}^{2}\right)$.

H. stagnorum ( $\mathrm{r}=0.72$, Bonferroni adjusted $\mathrm{p}=0.00023$, Fig. 5). A significant positive association was found between $\boldsymbol{V}$. lindbergi and $\boldsymbol{H}$. stagnorum densities ( $\mathrm{r}=0.54$; Bonferroni adjusted $\mathrm{p}=0.036$ ).

The potential predator on members of the surfacedwelling guild Notonecta canariensis (cf. Spence 1983) tended to be more common in larger pools situated in the lower part of the studied section as indicated by t-tests of presence/absence data ( $t_{\text {area }}$ $\left.=2.19, \mathrm{p}<0.05 ; \mathrm{t}_{\text {position }}=2.24, \mathrm{p}<0.05\right)$.

\section{Discussion}

The distribution patterns of different species in relation to the environment primarily revealed that Gyrinus urinator and $G$. dejeani occurred in large and deep pools having proportionally little vegetation, whereas Velia lindbergi and Hydrometra stagnorum were more common in small, shallow pools with relatively more vegetation. Overail, the relationships with environmental variables were quite weak. Perhaps the fact that the Canarian semiaquatic Heteroptera fauna is very diluted (Andersen 1982) has led to wider niche widths compared to situations in more species rich regions. A test of this hypothesis should ideally involve studies in similar continental habitats using the same methods as in this study.

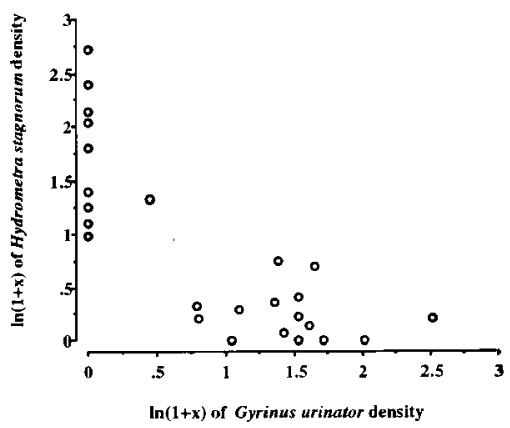

Fig. 5. The relationship between the densities of Hydrometra stagnorum and Gyrinus urinator.

Fig. 5. Relations entre les densités de Hydrometra stagnorum et Gyrinus urinator.

Only a few studies have dealt with the possible interspecific interactions among surface-living insects (Leech \& Chandler 1956, Spence 1983, Erlandsson 1992). These have shown that both predation and competition may be important agents in determining local guild structure. Such conclusions can not be drawn from our data, since no experiments were carried out. An extended study of the neuston community in Tenerife, or else where these species cooccur, should include particular attention to the species pair of $G$. urinator and $H$. stagnorum, which showed a negative association pattern (Fig. 5). Furthermore, a careful analysis of what food is eaten and what is the risk of predation to each species, including larval stages, would be desirable. Although most reports on food of these insects point at a great overlap (dipterans seem to dominate), a closer study might well reveal a partitioning along this niche axis which could help explain the coexistence of species. Further, it is possible that interrelations between species are influenced by seasonal differences in the degree of vegetation development. The more lush vegetation present in summer and autumn may facilitate coexistence through a higher microhabitat diversity and cover from predation, whereas more sparse vegetation in spring may increase interaction. 
Our data confirm earlier studies demonstrating interdependence between local abundance and regional distribution (Hanski 1982, Brown 1984), i.e. the most widely distributed species are also on average the most abundant. Although there was a tendency of distribution bimodality with few intermediate species, this pattern might be an artefact due to low species numbers (cf. Brown 1984).

Immigration rates from adjacent pools are probably high, since distances are short and pools are interconnected by riffle sections. Most adult insects could easily disperse by flight to any pool while larvae and most adult $\boldsymbol{V}$. lindbergi and $H$. stagnorum, are restricted to non-aerial dispersal. This means that dispersal downstream is always possible, while cascades of ten prohibit upstream movements. The relatively high z-value $(0.29)$ of the species-area relationship suggests that microhabitats might be missing (Diamond 1974). Similar high values have been recorded in other small habitat islands, such as small ponds (Lassen 1975).

In this context, it also might be interesting to draw attention to the fact that $V$. lindbergi, though predominantly flightless, showed a site-specific, variable degree of long-wingedness in this study and complementary samples, ranging from $\langle 5 \%$ to $>$ $12 \%$. Macroptery of the close relative $V$. caprai Tamanini has been reported to vary extensively between different parts of Europe, from fractions of one per cent (Brinkhurst 1959) up to $16 \%$ (Mielewczyk 1980, Brönmark et al. 1985). Similar variability (1.4-12.7\%) appears in $V$. saulii Tamanini (Mielewczyk 1980). It is not unlikely that there is a relationship between environmental characteristics and the frequencies of different wing morphs (cf. Vepsäläinen 1978).

G. thoracicus is also a wing polymorphic species (Andersen 1982), which on the sampling occasion in April was present only in its longwinged form in Barranco de Afur. Traits related to flying vs. nonflying individuals of this species have costs which in unpredictable environments include decreased longevity and, in permanent habitats, reduced fecundity (Kaitala 1991).

The sex ratio of $V$. caprai has been shown to be highly skewed (favouring females), although newly metamorphosed adults did not deviate from equal frequencies (Brönmark et al. 1985, Erlandsson et al. 1988). It is therefore interesting to note that also in $V$. lindbergi there tends to be a female bias. Brönmark et al. (op. cit.) suggested that intersexual competition could be an explanation of observed patterns.

Densities tended to be higher in large species (Fig. 2). This observation was unexpected since most previous studies have indicated decreasing densities with body size, or more precisely, a peak density near the smallest sizes and densities levelling off with increasing and decreasing size (Lawton 1989, 1990 , Blackburn et al. 1990). Theories of body size vs. abundance have many problems to consider. In our system, it is obvious that the fact that several species were represented by both adults and larvae is a major complicating factor (cf. Tokeshi 1990, who demonstrated non-existent density-body size allometry in a chironomid community). Considering only adults, the neustonic guild of predator/scavengers in Barranco de Afur clearly showed a markedly deviating pattern from that of many other systems. The two-dimensional habitat may cause enhanced levels of predation within the guild of neustonic insects and from transient predators (Andersen 1982, Brönmark et al. 1984), but also competitive interactions (Cooper 1984). Small species are likely to be the ones which suffer the most, at least in a situation of interspecific predation. More detailed studies should establish the possible use of alternative habitats by the smaller species and include experiments testing the prerequisites of species coexistence.

In conclusion, the eight species guild of surfaceliving predator/scavengers in the stream in the Afur valley conformed to earlier studies of abundancedensity and island biogeography patterns, but not to those of body size vs. population density. Individual species showed several characteristics concerning their local distribution, some of which probably contain explanations for their coexistence. Our data also provide new ecological information about little known species.

\section{Acknowledgements}

We are greatful for economic support from the Swedish Institute. Rolf Lidberg kindly helped to identify aquatic and riparian plants. Göran Arnqvist provided constructive and helpful criticism on the manuscript. 


\section{References}

Andersen N.M. 1982. - The semiaquatic bugs (Hemiptera, Gerromorpha). Entomonograph., Vol. 3. Scand. Science Press, Klampenborg, Denmark.

Anderson N.H. \& Wallace J.B. 1984. - Habitat, life history, and behavioral adaptations of aquatic insects. In : Merritt, R.W. and Cummins, K.W. (eds.), 2nd ed., An introduction to the aquatic insects of North America. Kendall/Hunt Publishing Company, Dubuque, USA : 38-58.

Balke M., Hendrich L. \& Cuppen J.G.M. 1990. - Wasserkäfer von den Islas Canarias (Coleoptera : Haliplidae, Dytiscidae, Gyrinidae, Hydrochidae, Hydrophilidae, Hydraenidae, Dryopidae). Entomofauna 11 : 349-376.

Blackburn T.M., Harvey P.H. \& Pagel M.D. 1990 - Species number, population density and body size relationships in natural communities. J. anim. Ecol., $59: 335-345$.

Brinçk P. 1955. - Gyrinidae. A monograph of the whirligig beetles of southern Africa. S. Afr. Anim. Life $1: 329-518$.

Brinkhurst R.O. 1959. - Alary polymorphism in the Gerroidea (Hemiptera-Heteroptera), $J$. anim. Ecol, $28: 211-230$.

Brönmark C., Malmqvist B. \& Otto C. 1984. - Anti-predator adaptations in a neustonic insect Oecologia $61: 189-191$.

Brönmark C., Malmquist B. \& Otto C. 1985. - Dynamics and structure of a Velia caprai (Heteroptera) population in a South Swedish stream. Holarct. Ecol., 8 : 253-258.

Brown J.H. 1984. - On the relationship between abundance and distribution of species. Am. Nat. $124: 255-279$.

Cooper S.D. 1984. - The effect of trout on water striders in stream pools. Oecologia $63: 376-379$.

Diamond J.M. 1974. - Colonization of exploded volcanic islands by birds : the supertramp strategy. Science $184: 803-806$.

Ekblom T. 1926. - Morphological and biological studies of the Swedish families of Hemiptera-Heteroptera. Zool. Bidr. Uppsa. $10: 29-179$.

Erlandsson A. 1992. - Interspecific interaction in semiaquatic insects : an experimental study. Oecologia. $90: 153-157$.

Erlandsson A., Malmqvist B., Andersson K.G., Hermann J. \& Sjöström P. 1988. - Field observations on the activities of a group-living semiaquatic bug. Velia caprai. Arch. Hydrobiol. $112: 411-419$

Hanski I. 1982. - Dynamics of regional distribution : the core and satellite species hypothesis. Oikos $38: 210-221$.

Heiss E. \& Baez M. 1990. - A preliminary catalog of the Heteroptera of the Canary Islands. Vieroea $18: 281-315$.

Holm S. 1979. - A simple sequentially rejective multiple test procedure. Scand. J. Statist. $6: 65-70$.

Istock C.A. 1966. - Distribution, coexistence, and competition of whirligig beetles. Evolution $20: 211-234$.
Kaitala A. 1991. - Phenotypic plasticicty in reproductive behaviour of water striders : trade-offs between reproduction and longevity during food stress. Funct. Ecol. 5 : 12-18.

Kolmes S.A. 1984. - Ecological and sensory aspects of prey capture by the whirligig beetle Dineutes discolor Coleoptera : Gyrinidae). N.Y. Ent. Soc. $91: 405-412$.

Lassen H.H. 1975. - The diversity of freshwater snails in view of the equilibrium theory of island biogeography. Oecologia 19: 1-8.

Lawton J.H. 1989. - What is the relationship between population density and body size in animals ? Oikos $55: 429-434$.

Lawton J.H. 1990. - Species richness and population dynamics of animal assemblages. Patterns in body size : abundance space. Phil. Trans. r. Soc. Lond. B. $330: 283-291$.

Leech H.B. \& Chandler H.P. 1956. - Aquatic Coleoptera. In : Usinger, R.L. (ed.), Aquatic insects of Calfornia, Univ, Calif. Press, Berkeley : 293-371.

Leopold L.B., Wolman M.G. \& Miller J.P. 1964. - Fluvial processes in geomorphology. W.H. Freeman, San Francisco.

Malmqvist B., Nilsson A.N., Baez M., Armitage P.D. \& Blackburn J. (in press). - Stream macro-invertebrate communities in the island of Tenerife. Arch. Hydrobiol. Suppl.

Mielewczyk S. 1980. - Zur Ökologie, Biologie und Morphologie von Velia saulii Tam. und $V$. caprai Tam. (Heteroptera, Veliidae). Annls Zool. $35: 285-305$.

Sedell J.R., Reeves G.H., Hauer F.R., Stanford J.A. \& Hawkins C.P. 1990. - Role of refugia in recovery from disturbances : modern fragmented and disconnected river systems. Env, Mgmt 14: $711-724$.

Spence J,R. 1981. - Experimental analysis of microhabitat selection in water-striders (Heteroptera : Gerridae). Ecology 62 : $1505-1514$.

Spence J.R. 1983. - Pattern and process in co-existence of waterstriders (Heteroptera : Gerridae). J. anim. Ecol. 52 : 497-511.

Tokeshi M. 1990. - Density-body size allometry does not exist in a chironomid community on Myriophyllum. Freshwal. Biol. $24: 613-618$.

Usinger R.L. 1956, - Aquatic Hemiptera. In : Usinger R.L. (ed.), Aquatic insects of California, Univ. Calif. Press, Berkeley, pp. 182-228.

Vepsäläinen K. 1973. - The distribution and habitats of Gerris Fabr. species (Heteroptera : Gerridae) in Finland. Amm. Zool. Fenn. $10: 419-444$.

Vepsäläinen K. 1978. - Wing dimorphism and diapause in Gerris : Determination and adaptive significance. In : Dingle $\mathrm{H}$, (ed.), Evolution of insect migration and diapause, Springer Verlag, New York : 218-253. 